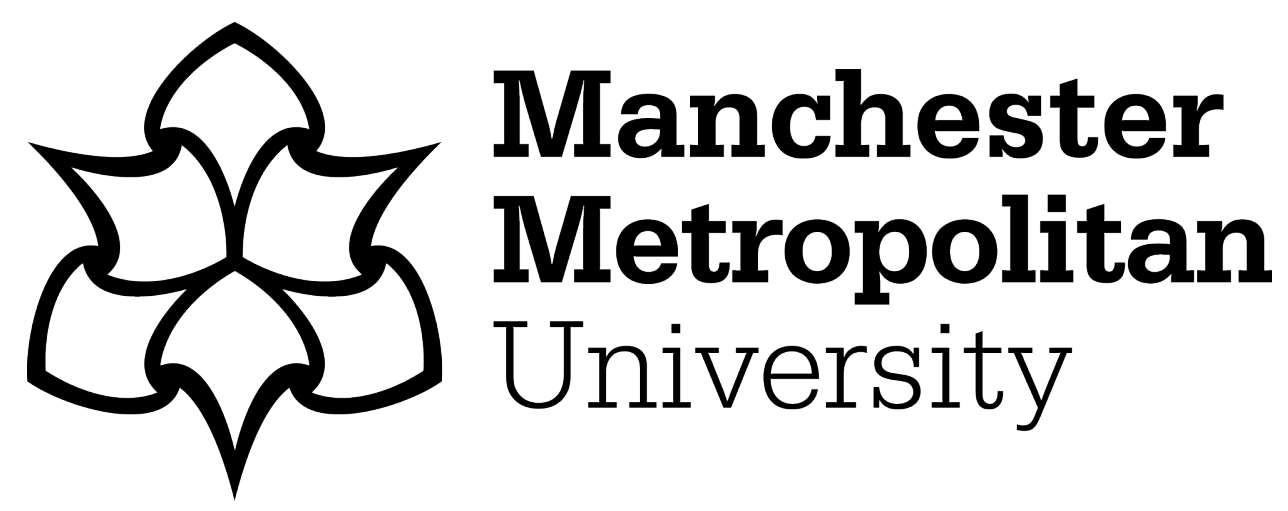

Melewar, TC and Skinner, Heather ORCID logoORCID: https://orcid.org/0000-0002-6505-8073 (2020) Why would anyone come to Corfu to have a Heineken? Qualitative Market Research: An International Journal, 23 (4). pp. 891-906. ISSN 1352-2752

Downloaded from: https://e-space.mmu.ac.uk/622939/

Version: Accepted Version

Publisher: Emerald

DOI: https://doi.org/10.1108/QMR-05-2018-0044

Please cite the published version 


\title{
Why would anyone come to Corfu to have a Heineken?
}

\begin{abstract}
Purpose: This paper examines brand naming decisions, along with other management decisions that affect tourist experiences, such as visitor tours, and souvenir appropriation, in the context of a microbrewery located on a Greek island that remains heavily dependent upon tourism.

Design/methodology/approach: Data were gathered from in-depth interviews with the microbrewery's owner and senior management team to offer rich insights into the issues under investigation.

Findings: Findings stress the importance of the meanings that can be conveyed through brand names, including those that indicate authenticity of the brand's origin, filling previously identified gaps in the literature on Country Of Origin with regard to fast consuming goods, and low involvement products such as beer, and exploring the issue of experiential consumption of beer as part of the tourists' vacation experience.

Research limitations/implications: Data were gathered from only a single company, and although highlighting important managerial decisions regarding brand naming, further research could be widened to other companies and other industries, and could explore these issues from the tourists own perspective rather than solely from a managerial perspective.

Practical implications: Results may offer insights for local producers, particularly SMEs, whose markets serve both domestic and tourist consumers.

Originality/value: This research furthers knowledge into gaps on a range of issues arising in the literature that have hitherto not been previously linked, specifically: product Country Of Origin / brand origin; cultural consumption of beverages and sense of place; issues of authenticity; souvenirs; and experiential consumption.
\end{abstract}

Keywords - authenticity, experiential consumption, souvenirs, beer, brewery tours

Article Classification: Research paper 


\section{Why would anyone come to Corfu to have a Heineken?}

\section{Introduction}

Gastronomic, or culinary tourism, has been receiving a lot of recent attention in the literature, as this form of tourism is seen to contribute to deep, meaningful, and memorable tourism experiences (Li, et al., 2018). Yet much of the extant literature considers these issues from the demand side of the consumer rather than considering the managerial decisions of the supplier (Kline, Greenwood and Joyner, 2015; Melewar and Skinner, 2018).

Within this body of literature much has also been written about authenticity. When related to food and drink, this can include authenticity claims about the Country of Origin (COO) of gastronomic products (Melewar and Skinner 2018), how food and drink is produced, or how it connects the consumer with the producer and the culture, heritage and traditions of a place and the tourism experiences that it offers (Kline, Greenwood and Joyner, 2015). Even though there is a well-established and broad body of literature on COO, gaps do remain that this paper will attempt to fill as part of its contribution to knowledge. There is limited COO research into fast moving consumer goods (FMCG), and low involvement products (Phau and Suntornnond, 2006), the effect of $\mathrm{COO}$ and other elements that may have an effect on purchasing (Eroglu and Marchleit, 1989), and into not only country of origin of a product, but also 'to more specific geographic origins such as regions’ Orth, McGarry Wolf and Dodd (2005:89).

The distinctive gastronomy a tourist can experience can contribute to attracting them to a particular destination (Seal and Siramanayagam, 2018). Local, authentic, place-specific food and 
drink can not only distinguish one destination from another, but also contribute to a destination's branding and brand identity (Berg and Sevón, 2014). Local food and drink is also a part of a destination's culture, and thus can represent this culture to tourists, providing a more authentic experience for those who consume the local produce (Seal and Siramanayagam, 2018). It is also recognised that even 'foodie' tourists comprise many different segments, and it would therefore not be the most effective strategy to treat them homogeneously (Kline, Greenwood and Joyner, 2015).

Yet the focus in this article is not the culinary tourist whose primary motivation is to experience local food and drink of a destination (Li, et al., 2018), rather it is focusing on the managerial decisions of a local beer producer attempting to attract tourists to sample and enjoy a local, authentic product in order to facilitate a more authentic destination experience whereas otherwise they may be more easily attracted to consuming more well-known beer brands produced by the two major global companies whose products dominate the market. This paper therefore examines brand naming decisions, along with other management decisions that affect tourist experiences, such as visitor tours, and souvenir appropriation, in the context of a microbrewery located on a Greek island that remains heavily dependent upon tourism.

Some attention has been paid in the literature to $\mathrm{COO}$ and authenticity with regard to tourist souvenir purchases (Goo and Shen, 2011), particularly craft souvenirs (Basri and Bakhtiar, 2014; Littrell, Anderson and Brown, 1993), but less concerning the souvenir purchase of regional foods and beverages (Kolyesnikova and Dodd, 2008; Swanson and Horridge, 2004; Wilkins, 2011). Food and drink souvenirs are those that exhibit the distinctiveness of the specialities of the destination, demonstrating authenticity and being related to a destination's traditions and culture 
(Ho et al., 2018). Taking such souvenirs 'home from a trip can extend and enhance the tourism experience ... [because] a specialty product is a means of reliving a visitor experience because food souvenirs are a tangible symbol and reminder of travel ... [and] carries meanings related to the destination visited' (Ho, et al, 2018:771).

As the tourism and marketing literature is becoming more focused on experiential consumption, there has been research into wine tourists' experiential consumption (Bruwer and Alant, 2009; Kolyesnikova and Dodd, 2008) but fewer studies into the consumption of beer or brewery tours as part of the vacation experience (Mitchell and Orwig, 2002). Beer consumption is an 'ubiquitous activity' (Pettigrew, 2002:112), and beer is the second most consumed type of alcoholic beverage worldwide (World Health Organisation, 2014). The consumption of local beers often occurs as part of the tourist's vacation in a destination, in addition to the purchase of beer and other related souvenirs, yet this type of local product souvenir differs in many ways from the other tangible objects in Gordon's (1986) original souvenir typology. Moreover, the beer market, particularly in Greece which is the context of this research, is heavily saturated with global brands, with two large multinationals dominating the market, although there do remain a few smaller local beer producers.

Even though it does not focus specifically on food tourists, this article does fall within the literature on food tourism, as it touches on the brewery tours, tasting experiences, and the company's beer festival, that definitely fits with food tourism's focus on the participation of tourists 'in food-related activities ... experience the local food and beverages, and have the opportunity to have authentic experience(s)' with the local specialities unique to the destination (Li et al., 2018:277). The brewery's annual week-long festival invites international guest 
breweries to showcase their beers, local food producers to exhibit, and features music and dancing from the local and international communities. This event does attract craft beer tourists, as do the open brewery tours that are held every Saturday during the main tourist season.

However, both events attract not only those who purposefully 'travel to experience beer culture, taste beers, or tour facilities' (Bradley et al, 2017:153), but also those who are simply engaging with the experiences as part of their holiday activities because they found out about the activities through the promotional efforts of the brewery, local tour operators, or from other tourists via resort-based social media groups once they had reached their destination.

In summary, this paper will contribute to filling gaps in the literature on COO and FMCG, particularly as these relate to managerial decisions concerning the supply side of gastronomy and tourism, and how these are contributing to the authenticity debate and being designed to attract not only those whose primary motivation for travel is consumption of local, distinctive and authentic products, but also those who can be swayed away from what has been produced by large global players in such markets.

\section{Literature Review}

In today's global market, COO may mean the country of a product's manufacture or production, the country of assembly, or the country in which the company owning the product brands is located. In an attempt to clarify such matters, Thakor and Lavack (2003:403) distinguish between consumer knowledge about associations with the brand's origin 'the country where the brand is owned' and consumer knowledge concerning COO, defined as 'the country where the product's parts are made or where the product is assembled'. 
Companies may choose to offer clues as to the country of origin $(\mathrm{COO})$ of a product through a brand name, however, not all such origin claims are authentic. Such inauthentic claims are referred to by Aichner, Forza and Trentin (2017:43) as 'the country-of-origin lie' when a company makes a deliberate naming decision to associate a product with a country that may be perceived as more favourable to consumers than the actual country of the product's origin. These authors also provide many examples of such practices that exist particularly in the global food and drink industry. This is enacted by companies that then use foreign languages or foreign sounding product names associated with a particular country to provide 'implicit country of origin cues' that may 'evoke associations' with the foreign country, which may then translate into persuading a consumer to purchase that product (Hornikx and van Meurs, 2017:60).

In their study into certain regional food and beverage brands from the North East of England, Lewis and Stubbs (1999:376) found that one brand, Tetley's bitter, had strong connotations to the Yorkshire region, 'but although these were viewed very positively within Yorkshire they were a two-edged sword outside the county'. 'It appears therefore that the issue of its region being the "natural home" of a product could be an important advantage to a brand, as long as there are no negative characteristics' (Lewis and Stubbs, 1999:380).

Given the focus of this study, it is pertinent when considering cultural consumption and sense of place to understand that, for island tourism, promoting the consumption of cultural products can aid a destination's 'sustainable identity, economy and ... viability' (Brown and Cave, 2010:87). However, it must also be noted that the way a nation's heritage may be represented 'through its cultural output, and also through the way various products and services are, authentically or not, associated with their country of origin ... becomes of more significance when considering the 
authenticity of the genius loci, and whether what is being promoted is authentic' (Skinner, 2011:287-288). Anderson and McAuley (1999) considered rural SME marketing in the West Highlands of Scotland. From a managerial perspective, such firms were seen to be extracting value from the environment, and differentiating their locally produced goods from others in the market. Tourist purchases were often driven by their quest for authenticity, especially when symbolising the sense of place of the product's origin.

A souvenir is a tangible, material object (Gordon, 1986) that acts as a reminder of an intangible significant experience (Anderson and Littrell, 1995; Cohen, 2000). Souvenirs can help an individual 're-live the experience in routine time and space' (Brennan \& Savage, 2012:147), evoking memories of the vacation and destination once the tourist has returned home. For the host destination, the production of authentic cultural artefacts can also bring economic benefits (Brennan and Savage, 2012). Examining issues of authenticity of craft souvenirs in Malaysia, Basri and Bakhtiar (2014) recognise the importance of SMEs in the production of such physical products, whether handmade or made by machine, that will be bought because they in some way offer a unique representation of the destination to which the tourist has travelled.

Craft souvenir production can also form part of the tourist's experiential consumption within the destination, especially if the tourist is able to see these souvenirs being made. Souvenirs are important to tourists, who spend approximately one third of their holiday spend on such items (Yu and Littrell, 2003). Yet, while tourists tend to spend a large proportion of their vacation spend on the purchase of souvenirs, souvenir research 'lacks depth ... remain descriptive' and fails to explore 'both their functional and symbolic dimensions' (Decrop and Massett, 2014:23). 
Since Gordon's (1986) identification of souvenir categories, further research has examined motivations to purchase either souvenirs as gifts, as memory, or as evidence (Wilkins, 2011), grouping these products into categories such as: Photographic / pictorial representations of the region; branded clothing; 'other items representative of the location / destination such as key rings / chains, fridge magnets, mugs'; regional arts and crafts; nonregional arts and crafts; 'other local speciality products such as regional food products, wine, clothing'; books, magazines and other published materials; and items including perfumes, electrical goods etc that can be purchased in the destination more cheaply than in the tourist's home country (Wilkins, 2011:242).

Specifically pertinent to this study is the category of local regional speciality products as souvenirs to consume once the tourist has returned home, purchased by tourists who want 'souvenirs reflective of the region, rather than more general items' (Wilkins, 2011:245). Products bearing a place brand name or identifiable visual features 'used to represent a place in logo form' can be seen as the place brand's merchandising (Medway, 2015:191). Many such products are also therefore purchased as souvenirs of a tourist's visit to that particular place. Medway (2015) offers examples from places strongly associated with food, such as the Italian city of Parma, where the place is 'promoted through incorporation of its toponym' in products such as Parma Ham, and the Aqua di Parma fragrance.

That such local speciality products are inherently imbued with authenticity has also been recognized by Swanson and Horridge (2004:379) who believe that an understanding of the importance of this authenticity to tourists offers a great opportunity for retailers to 'put effort into merchandise that fulfills the need for local products', including a focus on travel activities that 
may include attendance at local fayres and festivals, or when tourists are out and about eating and drinking in the destination, particularly if tourists are 'unfamiliar with the area and unaware of the novelty of local products'.

Baron and Harris (2010) who have forwarded the thinking into experiential consumption, have also categorised souvenirs as an 'experience enabler', forming part of the 'first-order interactions' a consumer may have on a vacation experience (along with interactions with other consumers, and other 'experience enabler' such as destinations themselves, service providers and their equipment). Tours of manufacturing plants, such as breweries, are consumption experience enablers, although the concept of authenticity also becomes relevant here, when considering if such tour experiences are more staged than authentic (Milman, 2013).

However, the importance of souvenir purchase as a way of extending the visitation experience has been recognised, even comparing the post-tour visit to a site shop as 'a collective pilgrimage' of an almost religious character, where visitors purchase souvenirs as 'an essential element to complement, strengthen, and extend in time the staging of re-enchantment of the experience' (Mencarelli and Pulh, 2012:157-158). Mitchell and Orwig (2002:32) identify that 'producers of consumer staples, such as food and beverages 'provide a disproportionate number of tours', recognising that, in their study on Consumer Experience Tourism (CET) in the United States, 'both wine and beer producers provide experiences applicable to consumers of varying levels of product involvement'. However, whereas wine tourists may specifically visit a destination in order to engage in activities related to wine consumption, Greek islands are not particularly wellknown for their brewing or beer products, yet many tourists to Greek islands will consume beer as part of their regular vacation experience. 
While individual national or local beer product brands do remain in production, these are often now in the ownership of large global corporations who dominate the current market. In Greece, two companies dominate, holding between them $90 \%$ of the market. The largest of these, with around $75 \%$ of the Greek beer market is the Athenian Brewery, 'a member of the Netherlands' HeinekenNV, the third largest brewer worldwide'. The Athenian Brewery produces the Amstel, Heineken and Alfa beer brands that are found widely across Greece and the Greek islands. The Mythos Brewery has around 15\% of the Greek beer market, and 'is a subsidiary of Denmark's Carlsberg Group, the world's fourth-leading brewer' (Vrellas and Tsiotras, 2014:31). The Mythos Brewery produces the Mythos brand 'which has a loyal - some would say fanatical - following' (Vrellas and Tsiotras, 2014:36). Indeed, the beer brand Mythos is now available to purchase in 30 countries (Vrellas and Tsiotras, 2014), allowing many tourists the opportunity to consume the product at any time in order to re-create their Greek vacation experience. However, despite the dominance of these two corporations and their four main product brands in this market, in their 'Overview of the Greek Brewing Industry', Vrellas and Tsiotras do note the recent appearance of Greek microbreweries.

Whereas Phau and Suntornnond (2006) consider beer to be categorised among FMCG and low involvement products, Stach (2017) links memorable experiences to brand preferences in the FMCG context, and Bech-Larsen, Esbjerg, Grunert, Juhl and Brunsø (2007:7) believe that food and drink can convey 'cultural meaning' and are therefore 'significant beyond their utility and conventional value'. Pettigrew (2002:116) notes the link between beer consumption and the management of the consumer's self- image, with informants describing 'in detail the ways in which they manage their consumption decisions and consumption activities in an attempt to achieve their ideal self-images'. Such decisions and activities were found to include beer brand 
choices, and the way consumers sought to understand 'the possible symbolic meanings held by different brands' (Ibid. p118). Although that study was undertaken in an Australian context, Pettigrew also identifies the similarities between attitudes in Australia to beer consumption with those occurring in other societies.

Phau and Suntornnond's (2006) study, into the COO knowledge of beer brands by Australian consumers found that while "consumers do not rely on country of origin for unfamiliar brands evaluations .... the foreign brands available in the market such as Heineken and Beck's can make use of their country of origin images by emphasising their superiority in product quality and social acceptability' (Phau and Suntornnond, 2006:39). While some attempts have been made to understand consumer choice 'and/or associations of local, nonlocal/foreign and, in some cases, global brands that affect consumers' attitudes and likelihood of purchase', Eren-Erdoğmuş and Dirsehan (2017:266) also recognise the need for further studies into these issues. Their recent study was into global/local coffee shops, justifying this due to the coffee shop's place in global consumer culture, however their research focused on emerging markets, although noting that markets such as Turkey, that formed the context of their research, are now 'very brand intensive ... with an increasing number of local and regional brands along with global and joint venture brands' (Ibid. p267).

Schallehn, Burmann and Riley (2014) believe that 'an authentic brand will remain true to its identity', however, because beer is relatively ubiquitous, a beer brand does not have to be perceived as particularly unique or individual to be perceived as authentic. Zhou, Yang and Hui (2010:203) have introduced the concept of Confidence in Brand Origin identification (CBO) as a moderating factor on Perceived Brand Foreignness (PBF), a concept that is especially relevant 
'in a marketplace filled with uncertainty about actual brand origins due to the imitation strategies of local rivals and/or the localization movement of international players'.

Corfu Microbrewery offers only a small range of beers, but within this range are three distinct brands, Corfu Beer, the Ionian brand, and 1842, a low-alcohol ginger beer. The company also brews one-off ales for various special events, particularly their own Corfu Beer festival, held for the first time in 2013, a week-long event held in October that attracted around 10,000 local and tourist visitors. The company also offers brewery tours throughout the season, and sells souvenir merchandise to its visitors. The qualitative insights offered by this research will help inform understanding of the managerial decisions made by the brewery's owner and senior management team, particularly regarding the products brand naming decisions, and the way these contribute to communicating a connection to the place to those tourists to the island who are keen to engage in authentic consumption vacation experiences.

\section{Methodology}

Corfu Microbrewery was established in 2006 by Spyros Kaloudis and his son, Thanasis, and produced its first beers in 2009. The company's aim was to create beers with a local Corfiot character, targeted at tourists, local inhabitants of the Greek island of Corfu, and also to geographically close export markets in other of the seven Ionian Islands and on the Greek mainland. In contrast to many larger global beer producers, Corfu Microbrewery focuses on producing only a 'natural living product', 'real ale', which is typical of the traditional brewing industry (Pitta and Scherr, 2009) but with no preservatives at all. This microbrewery is heavily reliant upon tourism in the summer months, but also serves local and geographically near export markets to extend their sales throughout the year of a seasonal product with a short shelf life due 
to its freshness and lack of preservatives. Links can therefore be drawn between the focus of this study and with many rural destinations that need to serve both tourists' and local residents' needs, in order to 'overcome obstacles of remoteness and seasonality' and to 'sustain economic growth (Hurst and Niehm, 2012:195).

Corfu Microbrewery is a family business. In-depth interviews with the microbrewery's owner (O) and four members of his senior management team, the Marketing Manager (MM), Sales Manager (SM), Financial Director (FD), and Communications Manager (CM) have provided the data for this research. In this respect, the data can be seen to have been drawn from a single case, in a single market, in a single country, and from a relatively homogeneous population, and with a very small sample (Boddy, 2016). Our approach can be justified in a number of ways: Firstly, the use of a single case study, while often receiving criticism, has been found to be appropriate when considering marketing decisions in a brewery context (Burghausen and Balmer, 2014; Lewis and Stubbs, 1999), and case study research (although using multiple cases) has also been employed by others researching managerial decisions in a brewery context (Geppert, Dörrenbächer, Gammelgaard and Taplin, 2013). Boddy (2016:426) stresses that even 'sample sizes involving one single case can be highly informative and meaningful as demonstrated in examples from management ... research', and that 'that individual (single sample) case studies can provide reliable indications for the directions in which future research can go. Individual cases can also provide a new, deep and nuanced understanding of previously unexplored phenomena' (p428). This reflects the view that single case studies can produce useful, even generalizable results if the case explores 'implications for current theory and conceptualizations of the issues explored' thus, 'the task of the researcher is thus to choose an appropriate case (or cases), to seek patterns, to develop assertions, to anticipate generalizations in a provisional manner, to link conclusions to 
current theory' (Buchanan, 1999:S77). Whereas a sample size of 12 is often recommended for such small-scale qualitative research, particularly when focusing on a 'single market/country or relatively homogeneous population', data saturation has also been found 'evident at six in-depth interviews' (Boddy, 2016:429), concluding that 'in these cases a single case study involving a single research participant can be of importance and can generate great insight. This logically means that the smallest acceptable sample size in these types of qualitative research is a sample of one' (p430).

The data for this study were drawn from only 5 in-depth interviews, but these informants were all members of the senior management team of a microbrewery, a very small family business, whose insights provided very rich data addressing the main aim of this study, to examine the company's brand naming decisions, along with other management decisions that affect tourist experiences, thus providing original insights into recognised gaps in the literature that have hitherto not been previously linked, specifically: product Country Of Origin / brand origin; cultural consumption of beverages and sense of place; issues of authenticity; souvenirs; and experiential consumption.

Interviews lasted around one hour each. Data were transcribed from tape recordings, with additional data provided from the company in the form of printouts of e-mails received from customers. Data were manually analysed thematically to elicit findings relevant to the themws under investigation. In the case of this article, these were:

- Company and product brand naming decisions

- Local product authenticity in a market dominated by global players

- $\quad \mathrm{COO}$ and its relationship to other factors 
- Events and brewery tours

- Souvenir purchase and appropriation

- Experiential consumption

\section{Analysis and Discussion of Findings}

\section{Company and product brand naming decisions}

The owner of this company grew up in Arillas, a small local village in the North West of Corfu within which he established his brewery. His family have lived in this village for generations. He and his senior management team feel a great pride not only in their company and in their products, but also in what these local products are doing for the village, the island and the wider Ionian Island region. This sense of pride is also felt by local people, not only in Arillas, but across Corfu. Initial discussions with the owner identified a clear distinction between the way the company and its products are named when presented to tourists compared with the way the company is named when targeting the local Greek speaking market in Corfu, and also the geographically near export markets targeted by the company on the mainland of Greece and on the other of the seven Ionian Islands under whose Prefecture Corfu falls. The company is generally known as 'Corfu Beer', a name that is reflected in one of its product lines, and is also

one of the legal entities established by the firm (Corfu Beer Ltd). However, the company has also established a legal entity in the name of 'Corfu Microbrewery Ltd, and while when written in English, the company name always appears as Corfu Beer, when written in the modern Greek

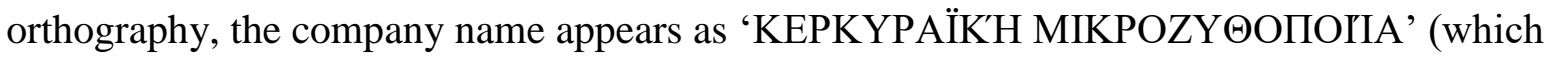
translates as Corfu Microbrewery). The company produces only a limited number of products, although adds to these regularly. Its current portfolio falls under two main product lines: the 
'Corfu Beer' and the 'Ionian' range. The Corfu Beer brand name encompasses the company's Dark Ale Bitter, Real Ale Special, Contessa IPA and the Amorosa Weiss. The Royal Ionian product range comprises the bottled Royal Ionian Pilsner, its keg version, the Ionian Gold, and the Ionian Epos dark beer produced with barley malt and honey. The most recent addition to this brand family is the Royal Ionian Ginger Ale. The company also produces a low-alcohol ginger beer under the brand name 1842, and 2 soft ginger ale drinks under the Royal Ionian brands, one flavoured with lemon, the other with orange and cinnamon.

The Corfu Beer brand is most widely sold on the island itself and in its mainland markets in Athens and Thessalonika, whereas the Ionian beers are available in Corfu and also more widely across the other Ionian Islands. Although Corfu Beer has produced two seasonal products for special beer festival events, the company mainly addresses seasonality by extending its market to mainland Greece throughout the winter months. This is unlike many other real ale brewers for whom seasonality is more often addressed by producing 'seasonal' beers (Pitta and Scherr, 2009). The reason for this in this case may be found less in industry sector, and more in in the geographical location of Corfu as an island tourism destination, where businesses seek to address issues of seasonality, while also seeking to serve and build relationships both with tourists and local consumers (Hurst and Niehm, 2012). There is a clear rationale for having both the Corfu and Ionian brand names. The sales manager stressed that "if you go in Kefalonia ... they say, OK I want to sell Kefalonia beer", which is why the owner specifically created both the Corfu Beer and Ionian Brands. As evidenced by the marketing manager "Corfu can sell, and Ionian can sell" [MM]. The brand naming decisions made by this company bears out earlier research by Lewis and Stubbs (1999) into beer brands that are imbued with a sense of place due to their brand name. 'Corfu' has positive connotations on the island itself, and also on the mainland of Greece, but 
retail outlets on the other Ionian Islands would respond less favourably to stocking a 'Corfu Beer', and so the decision to produce an 'Ionian' brand for these markets would seem to be an effective strategy.

\section{Local product authenticity in a market dominated by global players}

Similar to the results found when considering local versus global brand associations in coffee shop culture, we found in the case of Corfu Beer that 'brand relationship and differentiation can be created by local brands through highlighting the intangible benefits of belongingness to the [local] culture with authentic local products and experiences' (Eren-Erdoğmuş and Dirsehan, 2017:281). Bearing out previous research that identifies a tourist's interest in purchasing local regional speciality products (Kolyesnikova and Dodd, 2008; Swanson and Horridge, 2004; Wilkins, 2011), when travelling around Europe, the owner noted that "you drink the local beer, the local beer is something very exciting to the people to the local identity ... so when they come here, they come here to see what we have ... We are here, we are local products". "Visitors seem 'very enthusiastic when they come here, they feel very, I don't know why, they feel very good here, when they taste the beer they feel the difference from the other beers" [CM].

The owner also recognised that, when he started the company the dominant brand in the local market "was Amstel, the river in Holland, and I say 'no, no, I don't want to see this anymore"” For tourists, therefore, it is easy to explain the decision behind establishing a Corfu Beer brand. The owner questions why anyone would want to come to Corfu "to have a Heineken" [O].

When considering Thakor and Lavack's (2003) distinction between brand origin as country of ownership, and COO as where the product is actually made, the microbrewery can be seen to be 
authentically Greek, Ionian or Corfiot, depending on whether a country or regional approach is taken (Orth et al., 2005). Both the Athenian Brewery and Mythos Brewery, owned respectively by corporations based in the Netherlands and Denmark, could be seen to be Dutch and Danish brands, rather than Greek. Indeed, although the Athenian Brewery produce the Amstel and Heineken brands for the Greek market, these are both perceived as Dutch brands, whereas, based upon their brand names, the Athenian Brewery's Alfa brand, and the Mythos Brewery's Mythos brand are perceived as Greek (Aichner et al., 2017; Hornikx and van Meurs, 2017). However, when considering Zhou et al.'s (2010) concepts of Confidence in Brand Origin identification (CBO), consumers who have knowledge of the country of ownership of these brands may well start to perceive these brands as more 'foreign' than those of this microbrewery that can authentically claim a Greek brand origin as well as COO.

\section{COO and its relationship to other factors}

The company's beers are comparable in price to the larger global players. 'Our lager it's the same price, maybe cheaper than Mythos, on draft' [FD], 'but the brand is not that point, the point is the feelings that our brand create in the minds of local people or the people who come here for vacations' $[\mathrm{SM}]$. However, the management team does recognise that tourists may perceive the beer brands such as Alfa and Mythos as having an authentic Greek brand origin due to their Greek sounding names (Aichner et al., 2017; Hornikx and van Meurs, 2017). Yet they are keen to point out that "Mythos is not Greek, Alfa is not Greek, but they sell like they are Greek. But even if these beers were Greek, we are local here in Corfu" [FD].

Price sensitive consumers may prefer to purchase these global brands more than a local, more expensive, bottled real ale, but with the company paying close attention to price perceptions and 
value for money, and also producing a keg pilsner that is priced comparably to the Mythos brand, those local or tourist consumers for whom brand origin is important, and for whom consuming such a cultural product as local beer is important to convey a sense of place (Bech-Larsen et al., 2007), COO can be seen to work with, rather than in isolation from, other elements that may have an effect on their decision making (Eroglu and Marchleit, 1989).

\section{Events and brewery tours}

During the summer tourist season the company offers brewery tours and also stages a week-long Beer Festival in October. The owner also recognizes the positive effect that attracting tourists to the microbrewery can have on the local village. "Corfu Beer is not in the town ... We are in a small village in the North West of Greece ... more people know the microbrewery than the village ... and we can use this, can be a very good marketing for Arillas" [O]. The tours are authentic, and not staged (Milman, 2013), and currently take place in the main brewing area while the brewery workers get on with their daily brewing and bottling tasks. "We are the local product that presents Corfu and we feel very proud of it, and we want the people that come here to feel like home, and love our product like how we love it" the brewery's visitors "are very enthusiastic also about this because we are a very small company ... very very far from the Corfu Town" $[\mathrm{CM}]$.

The company's events and brewery tours are growing in popularity, and the company recognizes it needs to expand certain aspects of its operations to incorporate growing visitor numbers. "The plan is to fix the building to make a beer garden over there [pointing to the field over the road which is also owned by the company] with many events every year, so it will be, you know, there 
are many people interested to visit a microbrewery that you can see what happens here every Saturday morning" [O].

\section{Souvenir purchase and appropriation}

However, while the company does sell souvenirs to visitors to the microbrewery, they also find that some tourists appropriate souvenirs from the bars and tavernas where Corfu Beer is sold, particularly appropriating the Corfu Beer glass "we have a big problem, because they take it from everywhere, from the café's from the bars, they take it" [SM], although the Finance Director was relatively pragmatic about the problem, even seeing a positive side to it "I sort of see that sort of like as an unintentional marketing communication activity if you like". This is because this physical artefact is branded with the company logo. "The people they want to take with them something from Corfu, so they ask for T-Shirts, they ask for all that, everything in our logo they want to take ... Corfu Beer is Corfu beer, so I've been in Corfu and I drink Corfu Beer, so it's my souvenir from Corfu" [SM]. Again, bearing out previous research into the value of branded souvenirs that not only reflect the region but are authentic to the speciality products of the region (Swanson \& Horridge, 2004; Wilkins, 2011). Moreover, the merchandising offered by Corfu Microbrewery that bears the place name may be highly sought by consumers as a reminder of their trip not only to the island, but also to the brewery itself (Medway, 2015). The company currently supplies its branded beer glasses to its bar and restaurant customers to use when serving beer to their customers. However, even realizing the problem they have in replacing stolen 'souvenir' glasses, 'Many shops they ask can I buy these glasses and I sell to the people?' [SM] but the brewery does not yet provide glasses to these outlets to sell on as souvenirs to tourists. However, the sales manager does recognize the potential in the future to co-brand the beer 
glasses with the brewery logo along with the logo of the bar or restaurant, "our logo and the logo from the bar or from the café" [SM].

The company also receives e-mails from tourists "around the world that they came here and they taste the beer, and they want to have the beers at their homes ... many collectors also ... they write to us ... to send a coaster or a cup" $[\mathrm{CM}]$. The Communications Manager also presented some such e-mails, for example, from a customer from Germany, sent June 2014, "Saturday we left Corfu, finishing a great holiday. We tested Corfu Beer and now we want more. Is it possible to buy Corfu Beer in Germany, or to ship it?" Similarly, in August 2014 an e-mail was received from America. "I was active duty United States Marine Corps. On my last deployment I was able to stop in Corfu, Greece. And had the pleasure of trying Corfu red. It was delicious. I'm writing you today so that I may try to find out how I can order some to be shipped to the states. Or if you already ship to the USA, where can I go and get it!?” In July 2014 a customer even placed a preorder by e-mail Customer from the UK, pre-ordering his beer before coming out on holiday. 'I'm looking to get: 8 box's [sic] of royal Ionian (assuming 12 bottles a box), 2 box's of real ale bitter (assuming 12), 1 box of the ginger beer (assuming 24). If there is anything I can bring you from the UK please let me know. Also let me know if there is a festival this year ...”. However, as the beer is a fresh living product, made with no preservatives, it is not currently possible for this small company to export its beers further afield, and the owner does not yet want to consider licensing production of the company beers in foreign markets, unlike the brand Mythos (Vrellas \& Tsiotras, 2014), and Amstel, which as its bottle labelling in Greece states is "produced by Athenian Brewery S.A, ... under supervision of Amstel Brouwerij B.V. Holland”. 
The souvenirs that tourists purchase do not include only the beers themselves, available to purchase from the company shop, but also a wide range of merchandising that can help act as a reminder of the holiday (Ho, et al., 2018.). However, in this case it seems that the attraction of souvenir appropriation has been underestimated by the company who have left themselves open to souvenir theft, especially in the case of glasses that are taken away from the bars and restaurants through which it sells its beers. It is also not currently possible for the company to fill consumer demand for the beers to be available in export markets due to fresh organic nature of the product. Tourists do not only want to take souvenirs from the destination of their vacation to be consumed at home, as noted by Wilkins (2011). In the case of food and drink products, they also seem to wish to be reminded of their positive holiday experiences through the continued ability to purchase and consume the destination's speciality products once back in their home country.

\section{Experiential consumption}

The Marketing Manager is also keen to stress that the focus of all the company's activities is that the customer is happy and satisfied with their products. Recognising the experiential nature of consumption he wants to focus on the feedback about "the feelings that our brand create in the minds of local people or the people who come here for vacations" [MM].

This evidences the brewery's focus on facilitating the deep and meaningful experiential consumption that can be achieved through gastronomy (Li, et al., 2018), with the consumption of authentic local products, especially in high contact service experiences such as the brewery tours and events the company runs, connecting the tourist to the brewery and to the culture, heritage and traditions of the tourism destination (Kline, Greenwood and Joyner, 2015). In this case, the 
specific destination connection (Seal and Siramanayagam, 2018) is to Corfu, offering local beers, named with associations to the island, the Ionian region, and its history.

\section{Conclusion}

Because of this closeness to their most local market in Corfu, and because of their understanding of the regional market across the Ionian Islands, the brewery's owner and senior management team understand what meanings could be conveyed through their brands names to their local, tourist, and Greek mainland and Ionian Island export markets. The 'Corfu Beer' brand stakes as authentic a claim to both its brand origin and $\mathrm{COO}$ as does the 'Ionian' brand, and these claims can be seen to be authentically 'Greek' in all of its current markets, which are also located either on the Greek mainland or on the Ionian islands.

We believe that, although specific to the brewing industry, and although based on a single case study, our findings can offer practical insights concerning brand naming decisions that may offer clues to a product's place of origin, that may offer practical strategies for SMEs operating in markets serving both local and tourist consumers, particularly relevant to producers of local speciality products that may be consumed while on vacation as part of the tourism experience, or purchased alongside the brand's merchandising as souvenirs to extend the vacation experience.

The company has taken great care to ensure its brand and product naming decisions reflect its authenticity as a local Corfiot beer producer. While reflecting this authenticity in its naming decisions to meet the needs of both its local Corfiot and near export markets in Athens, Thessalonika, and the other Ionian islands (promoting the Corfu Beer brand more heavily on the island and the Royal Ionian brand in its other markets), these naming decisions can also help 
communicate place authenticity and distinctiveness, allowing the company to make good headway in a highly competitive market dominated by large global players.

We also believe we have made a contribution to knowledge in the areas of COO, cultural consumption and sense of place, and authenticity, particularly as our research is focused on filling two previously identified gaps in the literature on $\mathrm{COO}$ with regard to fast consuming goods, and low involvement products such as beer (Phau and Suntornnond, 2006), and as it relates to not only country of origin, but also region of origin (Orth et al., 2005).

COO does not work in isolation from other factors. This research has shown its relationship particularly with regard to price conscious consumers, and $\mathrm{COO}$ in relation to local and global producers who operate in the same markets. While consumers may be willing to pay more for authenticity, the company has taken great care to price its beers comparable to those of the more well known global brands.

With regard to the brewery tours and events the company holds, the company has recognized that these do not offer only the ability to promote the company's products, but also that they form an important part of the entire vacation experience, which, if enjoyable, can impact positively on the consumer's perceptions of the company, its products, and the whole destination experience. There are some further implications from this research that show where the company could improve its operations. These can be found particularly in the realm of merchandising and souvenirs. Corfu Microbrewery is a small company. While attempting to ensure all of its areas of operation are doing well, its main focus is on brewing beer. The company does recognize that tourists want to have souvenirs of their visit, and that the Corfu Beer logo represents a strong 
identifiable brand. However, the lack of will to consider exporting or overseas franchise production, while allowing the brewery to concentrate on quality production at home, is not serving consumer demand once a tourist has returned home yet still wishes to continue to purchase and consumer the company's beers. The company also takes a possibly too pragmatic view of the theft of its branded beer glasses. There may be less theft occurring if the company made it easier for customers to buy glasses from the outlets serving its products to tourists.

We have begun to explore the issue of experiential consumption of beer as part of the tourists' vacation experience, however this has been undertaken from a management perspective. Further research may fruitfully explore these issues from the tourists own perspective.

\section{References}

Aichner, T., Forza, C. and Trentin, A. (2017), "The country-of-origin lie: impact of foreign branding on customers' willingness to buy and willingness to pay when the product's actual origin is disclosed", The International Review of Retail, Distribution and Consumer Research, Vol. 27 No. 1, pp.43-60.

Anderson, A.R. and McAuley, A. (1999), "Marketing landscapes: the social context", Qualitative Market Research: An International Journal, Vol. 2 No. 3, pp.176-188.

Anderson, L.F. and Littrell, M.A. (1995), "Souvenir-purchase behavior of women tourists", Annals of Tourism Research, Vol. 22 No. 2, pp. 328-348.

Baron, S. and Harris, K. (2010), "Toward an understanding of consumer perspectives on experiences", Journal of Services Marketing, Vol. 24 No. 7, pp. 518-531

Basri, F.I. and Bakhtiar, M.F.S. (2014) "Craft souvenirs: perceived authenticity and tourist purchase behavior”, in Sumarjan, N., Mohd, Z.M.S., Mohd, R.S., Zurinawati, M., Mohd, H.M.H., Saiful, B.M.F., Artinah, Z. Bakhtiar, S. Hafiz, M. and Hanafiah, M. (Eds), Hospitality and Tourism: Synergizing Creativity and Innovation in Research, London: Taylor and Francis.

Bech-Larsen, T., Esbjerg, L., Grunert, K.G., Juhl, H.J. and Brunsø, K. (2007), “The Supermalt identity: how Brixton-based Afro-Caribbean consumers construct a Danish malt beer brand as one of their own”, Journal of Product \& Brand Management, Vol. 16 No.1, pp.5-15.

Boddy, C.R. (2016), “Sample size for qualitative research", Qualitative Market Research: An 
International Journal, Vol. 19 No. 4, pp.426-432.

Bradley, M.J., Maples, J., Lewis, A. and Berent, K.J. (2017), "Beer Tourism in Central Kentucky: Identifying On-Site Experience Preferences for Kentucky Brewery Tourists", Journal of Gastronomy and Tourism, Vol. 2 No. 3, pp. 153-161.

Brennan, L. and Savage, T. (2012), "Cultural consumption and souvenirs: an ethical framework", Arts Marketing: An International Journal, Vol. 2 No. 2, pp. 144-160

Brown, K.G. and Cave, J. (2010), "Island tourism: marketing culture and heritage - editorial introduction to the special issue", International Journal of Culture, Tourism and Hospitality Research, Vol.4 No. 2, pp. 87-95.

Bruwer, J. and Alant, K. (2009), "The hedonic nature of wine tourism consumption: an experiential view", International Journal of Wine Business Research, Vol. 21 No. 3, pp. 235-257.

Burghausen, M. and Balmer, J.M.T. (2014), "Corporate heritage identity management and the multi-modal implementation of a corporate heritage identity", Journal of Business Research, Vol. 67 No. 11, pp. 2311-2323.

Cohen, E. (2000), “Souvenir”, in Jafari, J. (Ed.), Encyclopedia of Tourism, Routledge, London and New York, pp. 547-548.

Decrop, A. and Masset, J. (2014), “'This is a piece of coral received from captain Bob': meanings and functions of tourist souvenirs", International Journal of Culture, Tourism and Hospitality Research, Vol. 8 No 1, pp. 22-34.

Eren-Erdoğmuş, İ. and Dirsehan, T. (2017), "Exploring local vs global brand associations in an emerging market using BCM technique", Qualitative Market Research: An International Journal, Vol. 20 No. 3, pp.266-288.

Eroglu, S. and Machleit, K.A. (1989), "Effects of individual and product-specific variables on utilising country of origin as a product quality cue", International Marketing Review, Vol. 6 No. 6, pp. 27-41.

Geppert, M., Dörrenbächer, C. Gammelgaard. J, and Taplin, I. (2013), "Managerial Risk-taking in International Acquisitions in the Brewery Industry: Institutional and Ownership Influences Compared, British Journal of Management, Vol. 24 No. 3, pp. 316-332.

Goo, Y-J. and Shen, M-J. (2011), "The relationship between authenticity and the souvenir purchase intent", Pan-Pacific Management Review, Vol. 14 No. 2, pp. 109-129

Gordon, B. (1986), "The souvenir: messenger of the extraordinary", Journal of Popular Culture, Vol. 20 No. 3, pp. 135-146.

Ho, C-I., Liu, L-W., Liao, H-H. and Yuan, Y. (2018), "conceptualizing perceived food souvenir quality: A formative approach", in Gursoy, D., Deesilatham, S. and Piboonrungroj, P. (Eds), 
Conference Proceedings: 8th Advances in Hospitality and Tourism Marketing and Management (AHTMM) Conference, June 25 - 29, 2018, Bangkok, Thailand, pp. 770-779.

Hornikx, J. and van Meurs, F. (2017), "Foreign Languages in Advertising as Implicit Country-ofOrigin Cues: Mechanism, Associations, and Effectiveness", Journal of International Consumer Marketing, Vol. 29 No. 2, pp.60-73.

Hurst, J.L. and Niehm, L.S. (2012), "Tourism shopping in rural markets: a case study in rural Iowa”, International Journal of Culture, Tourism and Hospitality Research, Vol. 6 No 3 pp. 194208.

Kline, C.S., Greenwood, J. and Joyner, L. (2015), "Exploring Foodie Segmentation”, Journal of Tourism Insights, Vol. 6 No. 1., Article 3

Kolyesnikova, N. and Dodd, T.H. (2008), "Effects of Winery Visitor Group Size on Gratitude and Obligation", Journal of Travel Research, Vol. 47, pp. 104-112.

Lewis, C. and Stubbs, S. (1999), "National expansion of British regional brands: parallels with internationalisation", Journal of Product \& Brand Management, Vol. 8 No. 5, pp.369-386.

Li, Z., Li, L., Xin, S. and Li, J. (2018), "The influences of gastronomy to different types of Chinese tourists - case of Chengdu", in Gursoy, D., Deesilatham, S. and Piboonrungroj, P. (Eds), Conference Proceedings: 8th Advances in Hospitality and Tourism Marketing and Management (AHTMM) Conference, June 25 - 29, 2018, Bangkok, Thailand, pp. 276-292.

Littrell, M.A., Anderson L.F. and Brown, P.J. (1993), "What Makes a Craft Souvenir Authentic?” Annals of Tourism Research, Vol. 20, pp. 197-215.

Medway, D. (2015), "Rethinking place branding and the 'other' senses", In: Kavaratzis, M., Warnaby, G. and Ashworth, G. (eds) Rethinking place branding, Switzerland:Springer International Publishing.

Melewar, T.C. and Skinner H (2018), 'Territorial brand management: Beer, authenticity, and sense of place', Journal of Business Research, https://doi.org/10.1016/j.jbusres.2018.03.038.

Mencarelli, R. and Pulh, M. (2012), "Museoparks and re-enchantment of the museum visits: an approach centred on visual ethnology", Qualitative Market Research: An International Journal, Vol. 15 No. 2, pp.148-164.

Milman, A. (2013), "Guests' perception of staged authenticity in a theme park: an example from Disney's Epcot's World Showcase”, Tourism Review, Vol. 68 No. 4 pp. 71-89.

Mitchell, M.A. and Orwig, R.A. (2002), "Consumer experience tourism and brand bonding", Journal of Product \& Brand Management, Vol. 11 No. 1, pp.30-41. 
Newey, L.R. and Zahra, S.A. (2009), “The Evolving Firm: How Dynamic and Operating Capabilities Interact to Enable Entrepreneurship, British Journal of Management, Vol. 20 No. S1, pp S81-S100.

Orth, U.R., McGarry Wolf, M. and Dodd, T.H. (2005), "Dimensions of wine region equity and their impact on consumer preferences", Journal of Product \& Brand Management, Vol. 14 No. 2, pp.88-97.

Pettigrew, S. (2002), “A grounded theory of beer consumption in Australia", Qualitative Market Research: An International Journal, Vol. 5 No. 2, pp.112-122.

Phau, I. and Suntornnond, V. (2006), "Dimensions of consumer knowledge and its impacts on country of origin effects among Australian consumers: a case of fast-consuming product", Journal of Consumer Marketing, Vol. 23 No. 1, pp.34-42.

Pitta, D.A. and Scherr, B.G. (2009), "The product strategy for seasonal products", Journal of Product \& Brand Management, Vol. 18 No. 2, pp.152-153.

Seal, P.P., and Siramanayagam, P. (2018), "Branding geographical indication (GI) of food and its implications on gastronomic tourism: an Indian perspective", in Gursoy, D., Deesilatham, S. and Piboonrungroj, P. (Eds), Conference Proceedings: 8th Advances in Hospitality and Tourism Marketing and Management (AHTMM) Conference, June 25 - 29, 2018, Bangkok, Thailand, pp. 132-137.

Schallehn. M., Burmann, C. and Riley, N. (2014), "Brand authenticity: model development and empirical testing”, Journal of Product \& Brand Management, Vol. 23 No. 3, pp.192-199.

Skinner, H. (2011), "In search of the genius loci - the essence of a place brand", The Marketing Review, Vol. 11 No.3, pp. 281-292.

Stach, S. (2017), "How memorable experiences influence brand preference", Qualitative Market Research: An International Journal, https://doi.org/10.1108/QMR-03-2016-0023

Swanson, K.K. and Horridge, P.E. (2004), “A Structural Model for Souvenir Consumption, Travel Activities, and Tourist Demographics”, Journal of Travel Research, Vol. 42, pp. 372-380.

Thakor, M.V. and Lavack, A.M. (2003), "Effect of perceived brand origin associations on consumer perceptions of quality”, Journal of Product \& Brand Management, Vol. 12 No. 6, pp.394-407.

Vrellas, C. G. and Tsiotras, G. D. (2014), "Operational Excellence in the Greek Brewing Industry”, Global Business and Organisational Excellence, Vol. 33, pp. 31-38.

Wilkins, H. (2011), "Souvenirs: What and why we buy", Journal of Travel Research, Vol. 50 No. 3, pp. 239-247. 
World Health Organisation (2014) Global Status report on alcohol and health 2014, available at: http://www.who.int/substance_abuse/publications/global_alcohol_report/msb_gsr_2014_1.pdf?u $\underline{\mathrm{a}=1}$ (accessed 13 November 2014).

Yu, H. and Littrell, M.A. (2003), "Product and Process orientations to tourism shopping", Journal of Travel Research, Vol. 42 No. 2, pp. 140-150.

Zhou, L., Yang, Z. and Hui, M.K. (2010), "Non-local or local brands? A multi-level investigation into confidence in brand origin identification and its strategic implications", Journal of the Academy of Marketing Science, Vol 38, pp. 202-218. 